Геліч Наталія, кандидат економічних наук, доцент, Східносвропейський національний університет імені Лесі Українки, кафедра аналітичної економіки та природокористування, м. Луцьк; ORCID ID 0000-0002-1568-1078, e-mail Gelich.Natalija@eenu.edu.ua

Панасюк Юрій, студент факультету економіки та управління, Східноєвропейський національний університет імені Лесі Українки, м. Луцьк, ORCID ID 0000-0001-8207-1926, e-mail Panasyuk.Iuriy@eenu.edu.ua

Оніщук Владислав, студент факультету економіки та управління, Східносвропейський національний університет імені Лесі Українки, м. Луцьк, ORCID ID 0000-0001-9528-6969, https://doi.org/10.29038/2411-4014-2020-02-143-151 e-mail Onishchuk.Vladyslav@ eenu.edu.ua

\title{
АЛЬТЕРНАТИВНА ЕНЕРГЕТИКА В УКРАЇНІ: СТАН ТА ПЕРСПЕКТИВИ РОЗВИТКУ
}

В даній статті здійснено оцінку сучасного стану в альтернативній енергетиці в Україні та світі, а також проведена оцінка досвіду інших країн 3 розвитку «чистої» енергетики. У зв’язку 3 постійним ростом споживання енергії постає питання розвитку альтернативних поновлювальних джерел енергії з мінімальним впливом на навколишнє середовище. В Україні вже протягом досить тривалого терміну діє «зелений тариф», але окрім цього, наша країна має можливість порівняти досвід різних країн в сфері альтернативної енергетики та використати найефективніші методи стимулювання розвитку альтернативної енергетики. При здійсненні стимулювання розвитку «чистої» енергетики необхідно враховувати також ії негативний вплив на навколишнє середовище та здійснювати заходи для його мінімізації.

Ключові слова: відновлювані джерела енергії, альтернативна енергетика.

Гелич Наталья, кандидат экономических наук, доцент, Восточноевропейский национальный университет имени Леси Украинки, кафедра аналитической экономики и природопользования; г. Луцк

Панасюк Юрий, студент факультета экономики и управления, Восточноевропейский национальный университет имени Леси Украинки, г. Луцк

Онищук Владислав, студент факультета экономики и управления, Восточноевропейский национальный университет имени Леси Украинки, г. Луцк

\section{АЛЬТЕРНАТИВНАЯ ЭНЕРГЕТИКА В УКРАИНЕ: СОСТОЯНИЕ И ПЕРСПЕКТИВЫ РАЗВИТИЯ}

В данной статье осуществлена оценка современного состояния в альтернативной энергетике в Украине и мире, а также проведена оценка опыта других стран по развитию «чистой» энергетики. В связи с постоянным ростом потребления энергии встаёт вопрос развития альтернативных возобновляемых источников энергии с 
минимальным воздействием на окружающую среду. В Украине уже в течение достаточно длительного срока действует «зелёный тариф», но кроме этого, наша страна имеет возможность сравнить опыт разных стран в сфере альтернативной энергетики и использовать эффективные методы стимулирования развития альтернативной энергетики. При осуществлении стимулирования развития «чистой» энергетики необходимо учитывать также её негативное воздействие на окружающую среду и осуществлять меры по его минимизации.

Ключевые слова: возобновляемые источники энергии, альтернативная энергетика.

\author{
Gelich Natalia, \\ Candidate of Economic Sciences, Associate Professor, \\ Lesya Ukrainka Eastern European National University, \\ Department of Analytical Economics and Nature Management, \\ Lutsk \\ Panasiuk Yurii, \\ student of the Faculty of Economics and Management, \\ Lesya Ukrainka East European National University, \\ Lutsk \\ Onishchyk Vladyslav, \\ student of the Faculty of Economics and Management, \\ Lesya Ukrainka East European National University,
} Lutsk

\title{
ALTERNATIVE ENERGY IN UKRAINE: STATE AND PROSPECTS OF DEVELOPMENT
}

This article assesses the current state of alternative energy in Ukraine and the world, as well as assesses the experience of other countries in the development of "clean" energy. Due to the constant growth of energy consumption, the question arises of the development of alternative renewable energy sources with minimal impact on the environment. As this issue is raised and studied in many countries for a long time, our country can compare foreign experience in this area and use methods to stimulate the development of alternative energy. Which proved to be the best. In Ukraine, the "green tariff" has been in force for a long time, the size of which is gradually decreasing, but in other countries, other methods of incentives have been positively recommended.. As a result of the work, the main directions of alternative energy were considered. It has been established that one of the best methods of stimulating the development of "clean" energy is the use of "green tariffs" and support through grants. Ukraine has quite progressive legislation in the field of green tariffs, but in our opinion this is not enough. The introduction of partial compensation for the cost of power plants from alternative energy sources can significantly accelerate the development of this industry. In addition, non-financial incentives, such as social advertising, should be used. When stimulating the development of "clean" energy, it is also necessary to take into account its negative impact on the environment and take measures to minimize it. When implementing alternative energy, it should be borne in mind that it can also harm the environment if used incorrectly. The negative impact of alternative energy can be reduced by using standardized norms, which define restrictions on the use of certain types of alternative energy under certain conditions.

Key words: renewable energy sources, alternative energy.

Постановка проблеми та її значення. Сучасні умови функціонування всіх сфер суспільства породжують постійно зростаючу потребу в забезпеченні електроенергією. Протягом останніх десятиліть споживання електроенергії в світі зростало стрімкими темпами. Якщо раніше зростаючу потребу можна було задовільними за допомогою традиційних джерел електроенергії, то сьогодні це стає складнішим, оскільки традиційні джерела $€$ вичерпними, тож через певний період часу закінчаться. Окрім того, їхнє використання є причиною заподіяння значної шкоди навколишньому середовищу. Якщо раніше шкода була мінімальна у зв’язку з порівняно незначним використанням традиційних енергоносіїв, то сьогодні вона $є$ помітною для звичайних людей, особливо в великих промислових центрах. Саме тому в багатьох країнах постало питання економічного стимулювання пошуку методів використання нових - відновних та екологічно чистих джерел енергії. Оскільки в Україні рівень розвитку альтернативної енергетики сфері $є$ незначним порівняно 3 провідними 
країнами світу, актуальним буде проведення оцінки сучасного стану рівня розвитку альтернативної енергетики в глобальному масштабі та рівня ефективності заходів зі стимулювання в різних країнах для можливості їх подальшого використання на території України.

Аналіз останніх досліджень і публікацій. Оскільки дане питання є актуальним, то сьогодні існує багато як зарубіжних так і вітчизняних вчених. Серед них особливо виділяються своїми працями Кудря С. О., Святненко А., Власов В. С., Петрук В. Г., Коцюбинська С. С., Мацюк Д. В., Ратушняк Г. С., Джеджула В. В., Бондаренко В. І., Варламов Г. Б. та інші.

Мета і завдання статті - розглянути стан розвитку альтернативної енергетики в світі в цілому та в Україні. Оцінити найбільш актуальні методи економічного стимулювання розвитку альтернативної енергетики зарубіжними країнами, та визначити їх актуальність для України.

Викладення основного матеріалу та обгрунтування отриманих результатів дослідження. Альтернативна енергетика поступово розвивається і поступово стає однією 3 основних галузей в світовій економіці. Відновлювальні джерела енергії не лише дозволяють зменшити залежність від традиційних джерел енергії, але також надають значні конкурентні переваги для країн, які їх ефективно використовують. А розвиток сучасних технологій та їх подальше впровадження на виробництві робить енергію, вироблену з «зелених» джерел дешевшою ніж аналогічну отриману за допомогою теплових електростанцій.

Для кращого розуміння перспектив розвитку даної галузі варто розглянути останні важливі події, що дають можливість оцінити рівень розвитку даної галузі у світі та ставлення світової спільноти до «зеленої» енергетики. Також це допоможе правильно оцінити сучасний стан та перспективи даної галузі в Україні.

С. О. Кудря визначає відновлювані або невичерпні енергоресурси як постійно або періодично діючі потоки енергії в навколишньому середовищі. Також науковець визначає дві основні групи енергетичних потоків з відновлювальних джерел електроенергії:

- енергія прямого сонячного випромінювання;

- вторинні прояви енергії сонячного випромінювання, що відображаються, як енергія вітру, теплова та гідроенергія, енеергія біомаси, тощо [2, с.10].

Використання відновлювальних енергоресурсів має чимало переваг, серед яких основними вважають практичну невичерпність та екологічну чистоту, що позитивно впливає на екологічний стан на планеті та не спричиняє зміну енергетичного балансу в біосфері. У випадку використання відновлювальних джерел електроенергії також зменшуються негативний вплив від процесів видобування, переробки, транспортування традиційних видів палива та відпадає потреба в утилізації великої кількості шкідливих відходів, що виникають при традиційному енерговиробництві [2, с.11].

Якщо розглядати динаміку потужності вітрових електростанцій на протязі останніх десятиліть, то стає помітною тенденція до іiї подвоєння протягом коних трьох років. Окрім того, на розвиток даної галузі майже не вплинули світові економічні кризи. В світі, протягом останніх п'яти років інвестиції в «зелену» енергетику зросли на 230\%. На протязі 2018-2019 років розмір інвестицій в дану галузь від країн великої двадцятки склав близько 32 мільярдів доларів щоквартально. Протягом даного періоду інвестиції в «чисті» енерготехнології в світі вперше в історії перевищили аналогічні інвестиції в створення традиційних енергетичних потужностей.

Протягом 2019 року потужність вироблення електроенергії з використанням відновлювальних джерел зросла і становила 250 ГВт. Як заявляють у свойй праці В. Власов та А. Святенко дана потужність дозволяє повністю забезпечити електроенергією близько 75 мільйонів домогосподарств. Протягом 2020 року прогнозується зростання потужності виробництва «чистої» електроенергії. Окрім того варто відзначити зростання у всіх секторах галузі. Протягом останніх п’яти років в світі відмічається приблизне щорічне зростання кількості виробленої сонячної електроенергії на $60 \%$, а вітрової - на 27\%. Також варто відмітити збільшення використання сонячної енергії для гарячого водопостачання серед домогосподарств (більше 70 млн.). Інтенсивність даної динаміки, на думку експертів, показує, що протягом поточного року відновлювальні та нетрадиційні джерела електроенергії в світі займуть друге місце після вугілля у виробництві енергії [3].

Підсумовуючи наведену вище інформацію, можна відмітити зростання ролі альтернативної та відновлювальної енергетики в світі, та концентрацію на сприянні та підтримці ії розвитку в світової спільноти. 
Окрім оцінки ситуації з «зеленою» енергетикою в світі, варто розглянути рівень розвитку даної галузі в Україні. На території України також можна відмітити тенденцію до зростання темпів розвитку відновлювальної енергетики протягом останніх років.

У вітчизняному законодавстві термін нетрадиційні та поновлювальні джерела енергії вперше був введений у 1994 році в Законі України «Про енергозбереження», де було не лише визначено основні поняття в даній сфері, але й встановлено основи правового регулювання, здійснюваного відносно фізичних та юридичних осіб, працюючих у сфері виробництва та відновлення об'єктів альтернативної енергетики. Окрім того, було одразу відмічено необхідність створення додаткових сприятливих економічних умов для розвитку підприємств в даній галузі за допомогою встановлення різноманітних пільг для виробників енергозберігаючого устаткування, обладнання, техніки та матеріалів, а також для підприємств, що при здійсненні господарської діяльності використовують електроенергію вироблену з альтернативних джерел [4].

2003 року Верховна Рада України прийняла закон «Про Альтернативні джерела енергії». В даному нормативно-правовому акті було регламентовано основні аспекти діяльності 3 використанням відновлювальних енергоджерел та забезпечено сприяння розширенню використання альтернативних та відновлювальних джерел електроенергії у вітчизняному паливно-енергетичному комплексі. Окрім того, було дано визначення альтернативної енергетики, як сфери енергетики, яка здійснює забезпечення виробництва електричної, теплової та механічної енергії з альтернативних джерел, а альтернативних джерел енергії - як відновлювальних джерел, що включають в себе сонячну, вітрову, геотермальну, енергію хвиль та припливів, гідроенергію, енергію біомаси, газу 3 органічних відходів тощо [5].

15 березня 2006 року Кабінет Міністрів України прийняв «Енергетичну стратегію України до 2030 року». Даний документ вважає нетрадиційні та відновлювальні джерела електроенергії важливим чинником зменшення впливу людини на навколишне середовище та зростання рівня енергетичної безпеки країни. Альтернативна енергетика виступає важливим фактором в покращенні глобальної екологічної ситуації та боротьбі зі змінами клімату на планеті. Саме тому розвиток даної галузі в Україні повинен здійснюватися з врахуванням зарубіжного досвіду, а напрями та методи стратегічного планування в даній сфері повинні сприяти міжнародним зусиллям з покращення ситуації в навколишньому середовищі. Це відображає не лише велике загальнодержавне, але й міжнародне значення використання потенціалу альтернативної енергетики в Україні. Позитивною характеристикою буде відповідність українського законодавства основним принципам «Європейської стратегії сталої, конкурентоздатної та безпечної енергетики», прийнятої в Брюсселі в 2006 році. Даною стратегією передбачено позитивні ефекти від розвитку відновлювальних джерел енергії [6].

Незважаючи на незначну частку відновлювальних джерел в загальному виробництві енергії, в Україні існує великий потенціал в даній сфері, що перевищує рівень споживання енергоресурсів в декілька разів.

Проте, в сучасних українських умовах не відображається тенденція до витіснення традиційної енергетики альтернативною в короткостроковій перспективі. Також існує значна залежність держави від імпортних джерел енергії, в тому числі нафти, газу та палива для ядерних станцій. У зв'язку 3 цим держава постає перед вибором між подальшим фінансуванням іноземних компаній з допомогою імпорту енергоносіїв та розвитком власних джерел електроенергії. Це також впливає на рівень подальшої енергетичної безпеки держави в майбутньому.

Оскільки держава має чималий потенціал щодо використання основних видів альтернативних джерел енергії, а також враховуючи постійне здешевшання альтернативної енергетики завдяки розвитку технологій та зниженню собівартості обладнання, незважаючи на нинішню низьку частку в загальному державному енергобалансі, можна говорити про значне підвищення вкладу «зеленої» енергетики в енергетичну незалежність країни [7].

До відновлювальних джерел енергії відносять сонячну, геотермальну енергію, тверду біомасу, біогаз, рідке біопаливо, гідроелектростанції, енергію припливів, хвиль океану, вітру, тощо. Для покращення розуміння перспектив розвитку альтернативної енергетики України доцільним буде розглянути основні відновлювальні джерела енергії, які характеризуються достатнім потенціалом для подальшого розвитку альтернативної енергетики країни. 
Біопаливо є одним з основних джерел альтернативної енергії на території України. Наша країна $\epsilon$ однією з країн з високим біоенергетичним потенціалом, проте, на жаль, сьогоднізначна частина біомаси, що може бути використана при виробництві енергії, вивозиться на звалища або просто знищується, а у вигляді палива використовується лише близько 1 мільйона тон. Варто відмітити поступове зростання сектору біоенергетики в Україні, що відображається, наприклад у заміщенні 3 допомогою біопалива трьох мільярдів кубічних метрів природного газу протягом 2014 року. За оцінками експертів, в сучасних умовах при наявних обсягах господарської діяльності ресурси біомаси, яку можна використовувати для вироблення енергії складають приблизно 20 млн. тон палива в рік.

Динаміка відображає зростання загальної кількості котлів, що працюють на біопаливі в бюджетній сфері та централізованому постачанні із 561 в 2012 році до 1878 у 2016 році, тобто більш ніж в 3 рази. Встановлена потужність за даний період зросла з 285 МВт до 1134 МВт (більш ніж в 4 рази). В муніципальному секторі України щорічний темп зростання ринку котлів становить приблизно 50\%. В довгостроковому періоді біопаливо та відновлюваний водень завдяки широкому впровадженню інноваційних технологій, можуть бути використані не лише на стаціонарних електростанціях, але і в авіації, судноплавстві та важкій промисловості.

Серед пріоритетних напрямків розвитку вітчизняної біоенергетики можна виділити створення соломоспалювальних котелень, та котелень для спалювання деревини, переоснащення працюючих TEC для забезпечення можливості спалювання органічних відходів промисловості, та побутової сфери.

До переваг використання біопалива також відносять можливість спалювання побічної продукції рослинництва, та використання відходів різноманітних виробництв, то також розвантажує звалища відходів. Використання біопалива не має значних недоліків.

На даний момент виділяють два способи використання сонячного випромінювання для виробництва електроенергії:

1. Джерело тепла (нагрівач для використання традиційних способів виробництва електроенергіi).

2. Безпосередній (пряме перетворення в електроенергію завдяки використанню сонячних елементів).

Окрім наведених вище способів, сонячне випромінювання використовується при дистиляції води, опалюванні, підігріві, а також при плавленні речовин. Дані результати отримують за допомогою концентрації сонячного випромінювання з використанням дзеркал.

Сьогодні в Україні існує значний потенціал у використанні саме сонячної енергії, оскільки вона $\epsilon$ легкодоступною як для великих підприємств, так і для звичайних домогосподарств, а існуюче державне стимулювання за допомогою зелених тарифів надає можливість навіть отримувати дохід повертаючи надлишки виготовленої електроенергії в електромережу. Проте, для кращого стимулювання використання сонячного проміння як джерела електроенергії Україні варто звернутися до успішного досвіду Польщі з частковою компенсацією вартості встановлення сонячних панелей домогосподарствам. Це вже спричинило значне зростання використання даного джерела електроенергії в даній країні.

Незважаючи на наявність передумов для розвитку вітчизняної сонячної енергетики, вона досі не отримала широке використання. За оцінками експертів даний напрям альтернативної енергетики може забезпечити економію до 6 мільйонів тон умовного палива щорічно. Потенціал розвитку сонячної енергетики забезпечує наявність необхідної металопродукції, власної промислової та наукової бази, конструкторських бюро, виробництва моно- та полікремнію тощо. Активне впровадження проектів фотоенергетики здійснюється з 2010 року.

Серед переваг сонячної енергетики виділяють загальнодоступність та невичерпність самого джерела енергії, що забезпечує майже повну безпеку для навколишнього середовища в процесі виробництва енергії.

Проте, даний вид альтернативної енергетики має чимало недоліків. Серед них виділяють:

- значний влив на продуктивність виробництва енергії часу доби, погоди та сезонних особливостей;

- вплив широти та особливостей клімату на потужність електростанцій; 
- необхідність використання значних площ для виробництва електроенергії (компенсується встановленням сонячних панелей на певній висоті над землею, або на житлових будинках);

- високу собівартість фотоелементів;

- наявність отруйних речовин (свинцю, кадмію, миш'яку тощо) в фотоелементах, забруднення навколишнього середовища в процесі виготовлення фотоелементів [7].

Ще одним напрямком в альтернативній енергетиці $є$ гідроенергетика. Вона $\epsilon$ досить добре освоєною, має постійно поновлювані ресурси та найнижчу собівартість серед усіх аналогів.

Протягом 2018 року гідроелектростанції виробили 8\% від загальної кількості електроенергії в країні [8]. Даний напрям енергетики може розвиватись за рахунок побудови нових ГЕС з потужністю 20-50 МВт та малих ГЕС на існуючих водних об’єктах.

Побудова малих та мікрогідроелектростанцій дозволяє частково забезпечити потреби споживачів в електроенергії, і стає ще більш привабливішою, враховуючи можливість побудови ГЕС на існуючих гідротехнічних спорудах, призначених для захисту від повеней.

Серед переваг ГЕС є постійний, природно поновлюваний енергозапас, стабільна кількість виробленої енергії, відсутнє забруднення навколишнього середовища. Основним недоліком гідроелектростанцій $є$ підтоплення здебільшого родючих земель та руйнування природного ландшафту [7]. Також можливий негативний вплив на популяцію морських організмів через перешкоди для їх вільного переміщення через водойми.

В Україні існують значні перспективи для розвитку вітроенергетики, у випадку освоєння потенціалів степових та гірських районів. Найбільш ефективною в даній сфері може бути територія південних та південно-східних областей України. За оцінками експертів, Україна може виробляти близько 15-20\% загальної кількості електроенергії за допомогою вітрових електростанцій.

До переваг вітрової енергетики відноситься іï повна екологічна чистота, оскільки вона не забруднює довкілля, споживаючи паливо. Серед недоліків відзначають звукове забруднення навколишнього середовища, необхідність виділення значних земельних територій для встановлення, та перешкоджання переміщенню різних видів комах.

Під кінець 2018 року установлена електрична потужність альтернативних джерел енергії (ГЕС, СЕС, ВЕС) становила 13\% відсотків, і залишилася незмінною з 2017 року. Дані показники відображають необхідність підвищення стимулювання розвитку альтернативної енергетики для досягнення необхідних показників визначених Енергетичною стратегією України до 2030 року щодо розвитку альтернативної енергетики [9].

Отже, сьогодні необхідно стимулювати розвиток альтернативної енергетики для зниження рівня залежності від традиційних енергоносіїв та підвищення ефективності загальносвітової політики в сфері екології та чистої енергетики.

Для визначення найефективніших методів стимулювання розвиту альтернативної енергетики доцільно буде розглянути досвід зарубіжних країн в даній сфері. Найефективнішим механізмом сприяння зростанню використання альтернативних енергоджерел $\epsilon$ введення «зеленого тарифу», тобто здійснення закупівлі «зеленої» енергії в виробників за завищеними тарифами. Даний метод вже використовується в 41 країні (більшість країн ЄС, Китай, Австралія, Канада).

Також, в певних країнах держава видає виробникам так звані зелені сертифікати, що дозволяє незалежно від обраного джерела альтернативної енергії, забезпечити однакові показники дохідності. До таких країн відносяться Великобританія, Болгарія, Італія, Польща, Швеція тощо.

Цікавим є довід Чехії зі звільненням виробників «чистої» енергії від ПДВ, а також країн, де такі виробники звільняються від усіх екологічних податків (Швеція, Франція, Нідерланди).

В деяких країнах ефективним себе показало стимулювання за допомогою грантів. Наприклад, 2010 року в США держава фінансово простимулювала на суму близько 500 мільйонів доларів будівництво нового заводу для виробництва сонячних панелей з використанням новітніх технологій. Німеччина також протягом тривалого часу здійснює стимулювання виробників обладнання для розвитку альтернативної енергетики за допомогою державних субсидій [3].

В вітчизняній практиці термін «зелений тариф» був вперше законодавчо визначений у 1997 році. Проте механізм його функціонування був розроблений лише в 2009 році. На думку експертів, даний закон є одним 3 найбільш прогресивних законів про «зелений тариф» в Європі. При розрахунку 
розміру тарифу в формулі враховуються різні коефіцієнти для основних альтернативних енергоджерел (сонячної, вітрової, гідроенергії, та енергій біомаси) [6].

Зелений тариф діє в Україні до 2030 року, тобто вже минула половина визначеного терміну його дії. Одним із заходів стимулювання стало зобов'язання щодо безперешкодного підключення альтернативних електростанцій до енергомереж. Також, враховуючи міжнародний досвід, було встановлено вимогу до претендуючих на «зелений тариф» інвесторів щодо використання української сировини, матеріалів, робіт при будівництві відповідного об’єкта у розмірі не менше $50 \%$ загальної вартості будівництва для підтримання вітчизняних виробників [10]. Сьогодні вже можна побачити позитивні результати від введення «зеленого тарифу» виражені в числових значеннях. Так, протягом 2015-2017 років було залучено близько мільярда доларів інвестицій та введено 958 МВт потужностей відновлюваної енергетики. Протягом 2018 році в дану галузь було інвестовано близько 500 мільйонів доларів [10].

Варто відмітити поступове зниження вартості зниження «зеленого тарифу протягом всього терміну його введення. Якщо на початку він становив 1015,38 коп/кВт.г для домогосподарств, то на період з січня 2020 до грудня 2024 року він становить 460,43 коп/кВт·год (без врахування ПДВ) [11].

Отже, вже існують основи для подальшого розвитку альтернативної енергетики в Україні, а чималий досвід інших країн повинен допомогти визначити правильні напрями стимулювання для забезпечення енергетичної незалежності та покращення стану навколишнього середовища.

Сьогодні одним із основних факторів збільшення використання та розвитку альтернативних джерел енергії $€$ значне зниження вартості виробництва обладнання внаслідок впровадження останніх досягнень науково-технічного прогресу. Дана ситуація підвищує економічну ефективність та прибутковість використання відновлювальних джерел енергії.

Певні технології використання відновлювальних джерел енергії, такі як геотермальна та гідроенергетика $\epsilon$ досить поширеними та конкурентоспроможними протягом досить тривалого періоду, проте помітна тенденцію до зростання обсягів виробленої електроенергії з використанням сонячної та вітрової енергії, що є наслідком впровадження інноваційних технологій та зростання привабливості даної сфери.

Серед інвесторів зникло упереджене вставлення до даної галузі як до такої, що вимагає значних фінансових вкладень, оскільки завдяки державній підтримці в даній сфері в багатьох країнах звичайні домогосподарства можуть дозволити собі встановлення, наприклад, сонячних електростанцій, та отримувати прибуток від передачі надлишків виробленої електроенергії в загальну мережу.

Окрім зниження вартості виробництва енергії з альтернативних джерел варто відмітити також тенденцію щодо зменшення витрат на іiі накопичення, що стало можливим завдяки значному зменшенню вартості виробництва літій-іонних акумуляторів. Очікується продовження даної тенденції протягом наступних десяти років. Експерти очікують, зниження середньої вартості електроенергії наземних вітрових установок до 2025 року на $26 \%$, морських - на $35 \%$, для технології концентрованої сонячної енергії - на $37 \%$, а для технології сонячної фотоелектрики - на 59\%. Також очікується зниження вартості стаціонарних акумуляторів $i$, як наслідок, здешевшання виробництва електроавтомобілів та інших електричних транспортних засобів.

Враховуючи високий рівень зношеності основних фондів в сфері класичної енергетики (середній термін роботи теплоелектростанцій складає 48 років), розвиток альтернативної енергетики стає ще більш привабливим. Сьогодні є очевидним, що в майбутньому в Україні як і в світі буде зростати обсяг інвестицій в використання відновлювальних джерел енергії. Державі залишається лише створювати для цього сприятливі умови, що може допомогти отриманню ефекту синергії.

Якщо робити висновки про стан та перспективи використання альтернативних джерел енергії надзвичайно важливим $є$ не лише врахування переваг, але також і розуміння недоліків «зеленої» енергетики. Так, наприклад вітрові електростанції мають значний рівень шуму, тому для їх розміщення необхідні чималі території, а також спричиняють перешкоди телебаченню. Використання сонячних електростанцій потребує виділення значних площ, а елементи що використовуються в фотоелементах мають в своєму складі, а також утворюють в процесі виробництва різноманітні отруйні речовини [12, с. 86]. 
Будівництво споруд гідроенергетики спричиняє підтоплення територій, всихання певних річок, зміну екосистеми водойм i, як наслідок, втрату біорізноманіття. Найменше негативного впливу здійснюється при використанні біомаси та бопалива. Проте Г. С. Ратушняк та В. В.Джеджула виділяють в своїй праці неефективне використання біодизеля, що виготовляється 3 ріпакової олії, оскільки при заправці одного автомобіля протягом року витрачається близько 1500 літрів олії, що, як відмічають науковці, рівноцінно території футбольного поля у випадку врожайності ріпаку до 3000 кг $з$ одного гектару [13, с. 54].

Незважаючи на законодавчо задекларовані кроки щодо стимулювання розвитку альтернативної енергетики сьогодні все рівно рівень розвитку нетрадиційної та відновлювальної енергетики $\epsilon$ недостатнім. Для пришвидшення розвитку даної галузі актуальним буде проведення роз'яснювальної роботи серед населення щодо важливості даної сфери та створення соціальної реклами, яка стимулювала б домогосподарства та підприємства використовувати альтернативні джерела енергії.

Висновки і перспективи подальших досліджень. В результаті проведеної роботи було розглянуто основні напрямки альтернативної енергетики. Встановлено, що одними із найкращих методів стимулювання розвитку «чистої» енергетики $\epsilon$ використання «зелених тарифів» та стимулювання за допомогою грантів.

Україна має досить прогресивне законодавство в сфері зелених тарифів, проте на нашу думку цього недостатньо. Впровадження часткової компенсації вартості електростанцій з альтернативних джерел енергії може значно прискорити розвиток даної галузі. Окрім цього, варто використовувати нефінансові способи заохочення, такі як, наприклад, соціальна реклама.

При впровадженні альтернативної енергетики варто враховувати, що вона також при неправильному використання може завдавати шкоди навколишньому середовищу. Негативний вплив альтернативної енергетики можна зменшити за допомогою використання стандартизованих норм, в яких визначено обмеження щодо використання тих чи інших видів альтернативної енергії за певних умов.

\section{Джерела та література}

1. Про внесення змін до деяких указів Президента України: Указ Президента України № 134/2012 від 22.02.2012. URL: https://zakon.rada.gov.ua/laws/show/134/2012 (дата звернення: 10.05.2020).

2. Кудря С.О. Нетрадиційні та відновлювані джерела енергії: підручник. К.: НТУУ «КПІ». 2012. 492 с.

3. Святненко А., Власов В. С. Отримати свою частину зеленого пирога. Тижневик «Дзеркало тижня» №47. 18.12.2010.

4. Про енергозбереження: Закон України» від 01 липня 1994 року. №74/94-BP. URL: https://zakon.rada.gov.ua/laws/show/74/94-\%D0\%B2\%D1\%80 (дата звернення: 10.05.2020).

5. Про альтернативні джерела енергії: Закон України від 20 лютого 2003 року. № 555IV. URL: https://zakon.rada.gov.ua/laws/show/555-15 (дата звернення: 10.05.2020).

6. Про затвердження Порядку встановлення, перегляду та припинення дії "зеленого" тарифу на електричну енергію для суб'єктів господарської діяльності та приватних домогосподарств: постанова Національної комісії, що здійснює державне регулювання у сфері енергетики № 1421 від 02.11.2012. URL: https://zakon.rada.gov.ua/laws/show/z1957-12 (дата звернення: 10.05.2020).

7. Потенціал відновлюваних джерел енергії в Україні. Agroexpert: веб-сайт. URL: https://agroexpert.ua/potencial-vidnovluvanih-dzerel-energii-v-ukraini/ (дата звернення: 10.05.2020).

8. Постачання та використання енергії/ Державна служба статистики України. URL: http://www.ukrstat.gov.ua/operativ/operativ2018/energ/pve/arh_pve u.htm (дата звернення: 10.05.2020).

9. Аналіз сучасного стану альтернативної енергетики та рекомендації по екологізації паливноенергетичного комплексу України. Промислова екологія: веб-сайт. URL: http://eco.com.ua/content/analizsuchasnogo-stanu-alternativnoi-energetiki-ta-rekomendatsii-po-ekologizatsii-palivno-e (дата звернення: 10.05.2020).

10. Альтернативна енергетика країни. Проблеми i перспективи. HTCEУ: веб-сайт. URL: https://www.ntseu.net.ua/stories/473-top-5-02-5 (дата звернення: 10.05.2020).

11. Про встановлення «зелених» тарифів на електричну енергію, вироблену генеруючими установками приватних домогосподарств: постанова Національної комісії, що здійснює державне регулювання у сферах енергетики та комунальних послуг № 725 від 25.03.2020. URL: https://zakon.rada.gov.ua/rada/show/v0725874-20 (дата звернення: 10.05.2020). 
12. Бондаренко В. И., Варламов Г. Б., Вольчин И. А. Энергетика: история, настоящее и будущее. От огня и воды к электричеству: монография. К., 2011. 264 с.

13. Ратушняк Г. С., Джеджула В. В. Енергозбереження в сільськогосподарській біоконверсії: навч. посіб. Вінниця: ВНТУ, 2006. 83c.

\section{References}

1. Pro vnesennja zmin do dejakykh ukaziv Prezydenta Ukrajiny: Ukaz Prezydenta Ukrajiny \# 134/2012 vid 22.02.2012 [On amendments to some decrees of the President of Ukraine: Decree of the President of Ukraine № 134/2012 of 22.02.2012]. Retrieved from: https://zakon.rada.gov.ua/laws/show/134/2012 [in Ukrainian].

2. Kudrja, S.O. (2012) Netradycijni ta vidnovljuvani dzherela energhiji: pidruchnyk [Unconventional and renewable energy sources: a textbook]. K.: NTUU KPI. 492. [in Ukrainian].

3. Svjatnenko, A., Vlasov, V. S. (2010) Otrymaty svoju chastynu zelenogho pyrogha [Get your share of green pie]. Tyzhnevyk «Dzerkalo tyzhnja» [Weekly "Mirror of the Week"] \#47.

4. Pro energhozberezhennja: Zakon Ukrajiny» vid 01 lypnja 1994 roku. \#74/94-VR [On energy saving: Law of Ukraine of July 1, 1994. №74 / 94-BP]. Retrieved from: https://zakon.rada.gov.ua/laws/show/74/94$\%$ D0\%B2\%D1\%80 [in Ukrainian].

5. Pro aljternatyvni dzherela energhiji: Zakon Ukrajiny vid 20 ljutogho 2003 roku. \# 555IV [On Alternative Energy Sources: Law of Ukraine of February 20, 2003. № 555IV]. Retrieved from: https://zakon.rada.gov.ua/laws/show/555-15 [in Ukrainian].

6. Pro zatverdzhennja Porjadku vstanovlennja, pereghljadu ta prypynennja diji "zelenogho" taryfu na elektrychnu energhiju dlja sub'jektiv ghospodarsjkoji dijaljnosti ta pryvatnykh domoghospodarstv: postanova Nacionaljnoji komisiji, shho zdijsnjuje derzhavne reghuljuvannja u sferi energhetyky \# 1421 vid 02.11.2012 [On approval of the Procedure for establishing, revising and terminating the "green" tariff for electricity for business entities and private households: Resolution of the National Commission for State Regulation of Energy № 1421 of 02.11.2012]. Retrieved from: https://zakon.rada.gov.ua/laws/show/z1957-12 [in Ukrainian].

7. Potencial vidnovljuvanykh dzherel energhiji v Ukrajini. Agroexpert: veb-sajt [Potential of renewable energy sources in Ukraine. Agroexpert: website]. Retrieved from: https://agroexpert.ua/potencial-vidnovluvanih-dzerelenergii-v-ukraini/ [in Ukrainian].

8. Postachannja ta vykorystannja energhiji: Derzhavna sluzhba statystyky Ukrajiny [Energy supply and use: State Statistics Service of Ukraine]. http://www.ukrstat.gov.ua/operativ/operativ2018/energ/pve/arh_pve_u.htm [in Ukrainian].

9. Analiz suchasnogho stanu aljternatyvnoji energhetyky ta rekomendaciji po ekologhizaciji palyvnoenerghetychnogho kompleksu Ukrajiny. Promyslova ekologhija: veb-sajt [Analysis of the current state of alternative energy and recommendations for the greening of the fuel and energy complex of Ukraine. Industrial ecology: website]. Retrieved from: http://eco.com.ua/content/analiz-suchasnogo-stanu-alternativnoi-energetiki-ta-rekomendatsii-poekologizatsii-palivno-e [in Ukrainian].

10. Aljternatyvna energhetyka krajiny. Problemy i perspektyvy. NTSEU: veb-sajt [Alternative energy of the country. Problems and prospects. NTSEU: website]. Retrieved from: https://www.ntseu.net.ua/stories/473-top-5-02-5 [in Ukrainian].

11. Pro vstanovlennja «zelenykh» taryfiv na elektrychnu energhiju, vyroblenu ghenerujuchymy ustanovkamy pryvatnykh domoghospodarstv: postanova Nacionaljnoji komisiji, shho zdijsnjuje derzhavne reghuljuvannja u sferakh energhetyky ta komunaljnykh poslugh \# 725 vid 25.03.2020 [On the establishment of "green" tariffs for electricity produced by generating installations of private households: Resolution of the National Commission for State Regulation of Energy and Utilities № 725 of 25.03.2020]. Retrieved from: https://zakon.rada.gov.ua/rada/show/v0725874-20 [in Ukrainian].

12. Bondarenko V.Y., Varlamov Gh.B., Voljchyn Y.A. (2011) Эnerghetyka: ystoryja, nastojashhee y budushhee. Ot oghnja y vodы k эlektrychestvu: monoghrafyja [Energy: history, present and future. From fire and water to electricity: a monograph] K., 264 [in Russian].

13. Ratushnjak, Gh.S. Dzhedzhula, V.V (2006) Energhozberezhennja v siljsjkoghospodarsjkij biokonversiji: navch. posib [Energy saving in agricultural bioconversion: textbook] Vinnycja: VNTU, 83 [in Ukrainian]. 